\title{
14. The Abau Open Electorate: A Second Go at LPV
}

\author{
Ray Anere
}

\section{The electorate}

The Abau Open electorate lies about 200 kilometres east of Port Moresby and at the 2000 census was home to some 38,378 people (National Statistical Office 2000:13).

There are three local-level governments (LLGs) in the Abau electorate: Aroma Rural LLG, with a population in 2000 of 20,677; Amazon Bay Rural LLG with 8099 people; and Cloudy Bay Rural LLG with 9602 (Figure 14.1). The fact that Aroma has more eligible voters than Amazon Bay and Cloudy Bay combined impacted on the conduct of the 2007 elections in terms of both the campaign strategies of the candidates and the Papua New Guinea Electoral Commission's (PNGEC's) conduct of the elections. Of the 12 candidates that contested the Abau seat, 10 were from the Aroma Rural LLG area.

Historically, Abau was the first to trial the new limited preferential voting (LPV) system, in a 2003 by-election. The system was successfully used in that byelection, with around 1.9 percent of informal ballots suggesting that most voters had understood the system and voted correctly. Dr Puka Temu, who had been elected in 2002 but lost the seat following an appeal, ${ }^{1}$ re-contested the seat and again won with 49.0 percent of first preferences, needing less than 2 percent of second preferences for an absolute majority. Only two eliminations took place before Temu won the seat with 50.1 percent of the total live votes. There were no exhausted ballot papers (Standish et al. 2004:28-29).

Figures of estimated adult population and eligible voters in the Abau District developed by Standish et al. (2004:5) suggest that the rolls in 2002 and 2003 were grossly inflated, with the number of 'eligible voters' (34,905 in 2003) exceeding the estimated adult population by 82 percent (and by 92 percent in the Aroma Rural LLG area). After the new roll had been drawn up, the number of eligible voters was 29,652 - a reduction of 15 percent but still excessive relative to

\footnotetext{
1 Temu, who had recently stood down as Health secretary in 2002, took delivery of an ambulance for the Amazon Bay LLG during the campaign, and rival candidate Kilroy Genia successfully objected that this amounted to 'treating'. The matter was taken to the Court of Disputed Returns which upheld the appeal and therefore ordered a by-election.
} 
estimated adult population. In 2007 the total number of votes cast was 22,037, giving an apparent turnout of 74.3 percent. In 2002 about 60 percent of those enrolled voted; in the 2003 by-election the figure was 53.1 percent (PNGEC, Voter Enrolment in Abau, 5 November 2009).

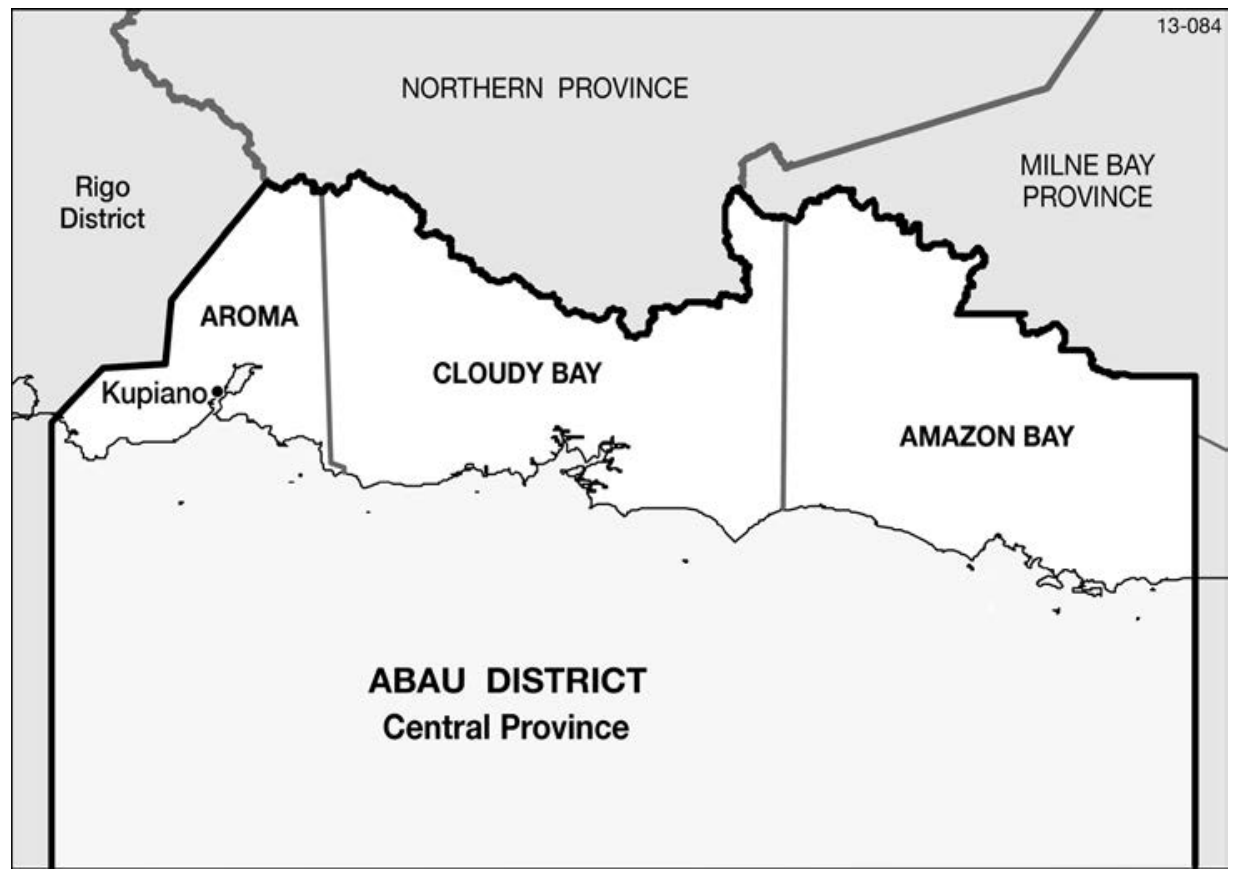

Figure 14.1: Abau District

The Abau electorate has gained prominence at the national level. Since 1987, the voters have elected leaders who have become senior ministers in the national government - the late Jack Genia, his brother Kilroy Genia, and Deputy Prime Minister Puka Temu. Electoral competition has been intense, with 18 candidates in 1987, 21 in 2002, 6 in the 2003 by-election, and 12 in the 2007 election.

Most candidates in previous elections have come from the Aroma Rural LLG area. In the 2003 by-election, for example, all six candidates-Vagi Mae, Puka Temu, Onea Thavala, Desmond Baira, Gideon Aruai and Kilroy Genia-were from the Aroma coast (Standish et al. 2004:6). The race narrowed to a contest between Temu and Baira. Tension rose between their supporters, who exchanged insults and gunfire. Standish et al. (2004) reported that the police opened fire in an attempt to quell the situation and a young man was shot dead. The conflict between Temu and Baira divided the electorate, and was evident again in the 2007 election. 


\section{Nominations}

Twelve candidates contested the Abau electorate in 2007, six of whom had contested the by-election in 2003. Eight of them (including the six who contested in 2003) were from the Aroma coast. There were no women candidates.

Temu was a National Alliance candidate. In 2002 he was elected, as a National Alliance candidate, with 29.6 percent of the vote under the first-past-thepost system. He was appointed minister for the Public Service but was ousted through a successful appeal to the Court of Disputed Returns by Kilroy Genia (see footnote 1). Temu, a medical doctor and former secretary of the Health Department, is from Viriolo village at the eastern end of the Aroma coast and has a grandfather from Wanigela village, with links to Waiori village, both in Marshall Lagoon.

Kilroy Genia contested the 2003 by-election as People's Action Party candidate. He entered parliament in a 1994 by-election after the death of his brother, Jack Genia, who was a previous MP and Pangu Pati leader. Between 1994 and 1997 he served as minister for Foreign Affairs and Immigration. Kilroy won again in 1997 and in 2002 he stood as a People's Democratic Movement candidate and came third with 19.2 percent of the vote. His father is from Domara village in the Cloudy Bay while his mother is from Lalaura village in Aroma. He has family ties in the Amazon Bay area.

Desmond Baira stood in the 2003 by-election as a People's Labour Party candidate. In 2002, he contested the Abau seat as a People's Action Party candidate and came second with 23.7 percent of the vote. He also contested the seat in 1992, 1994 and 1997. He is a Port Moresby-based contractor and is from Wanigela village. He also has links to Waioro village in the Marshall Lagoon area.

Reuben Kaiulo is a former electoral commissioner, and was commissioner when first-past-the-post voting was used for the last time in 2002. In his report on the 1997 election he was critical of proposals to introduce preferential voting (see Kaiulo 2002:179). After his term of office expired in 2005 he was self-employed. He had not contested any previous election. He was endorsed by Pangu. Kaiulo is from Lalaura in the Aroma coast and received most of his support from voters there.

All candidates nominated at the district office at Kupiano. The idea of holding nominations at Kupiano came from the PNGEC. The PNGEC was of the view that by having the nominations at the local district centre, with which people identify, the people would take ownership of the election. Each candidate gave a speech before their crowd of supporters, as it was important for the supporters 
to know what kinds of services the candidate would bring to their localities, and for the candidates to know that they could count on the votes of their supporters.

The election manager, provincial returning officer, and assistant returning officer were present at Kupiano during the nomination period. All nominations complied with the necessary requirements, and the process was orderly. The returning officer conducted the order of draw for the candidates, who were generally satisfied with the nomination process.

\section{LPV awareness}

Voters in Abau were not new to LPV as they had voted under the LPV system in the 2003 by-election. Turnout was higher in 2007 than in the by-election.

Initial LPV awareness involved organizing public servants into teams and senior district officials became assistant returning officers. Coloured LPV posters and stickers for vehicles ('LPV, 1, 2, 3-Now That's Fair!') were used as aids in carrying out the awareness. Voters generally understood that ' 1 ', ' 2 ' and ' 3 ' stood for the order of preferences, and understood that they had to write a candidate's name or code number against each of the three preferences in order to make their ballot formal.

Mock polls were undertaken by awareness teams in some places to give voters a taste of the real election. Some community members missed out on awareness sessions, however, due to lack of forewarning. Many voters listened to FM 100 and FM Central radio services to get information on LPV prior to the polling. Port Moresby-based residents travelling back to Abau were another source of information.

One civil society group, the Amazon Bay HIV/AIDS Committee, was involved in LPV and HIV/AIDS awareness in the Amazon Bay local government area, under the Electoral Support Program LPV awareness program. Committee members Freda Magini, Lahui Magini, Esau Frank and Fred Mae undertook six weeks of LPV awareness in various wards in the Amazon Bay area from May to June 2007. The wards included Borebo, Sabiribo and Aroana.

The LPV awareness covered the following topics: LPV 1st, 2nd and 3rd preferences; voting under LPV; counting under LPV; mock elections; election offences; good governance; HIV/AIDS and elections; and, women and elections. The good governance component covered leadership, democracy, and democratic elections. 
The LPV awareness activities undertaken by the committee were generally considered successful. Evaluation forms filled out by people in the wards covered showed that people understood what LPV was all about; how to vote in terms of the 1st, 2nd and 3rd preferences; the equal importance of all three preferences; and the meaning of ' $50 \%$ plus 1 ' of total allowable votes. Many people indicated that they were satisfied with the awareness undertaken by the committee. The Electoral Support Program was also satisfied with the committee's performance in carrying out the LPV awareness.

In the villages of Duramu, Domara, Moreguina and Baramata Number 4, in the Cloudy Bay local government area, no LPV or civic awareness activity was undertaken. However, in Aroma, LPV awareness was conducted by PNGEC staff and candidates in the Kapari-Viriolo ward. Mock elections were carried out using local citizens as candidates and counting officials. Several informants said that the mock elections involving local people were very beneficial in enhancing the people's understanding of the LPV system.

LPV and civic awareness, however, were not carried out in all wards in each local government area. Kapari, in the Aroma area, is the home of the sitting member, Puka Temu. As his support base, it was important for him to conduct LPV awareness there. Other wards in Aroma were not visited by LPV or civic awareness teams.

The success of LPV awareness in Abau is suggested by the fact that there were only 328 informal ballot papers, a mere 1.5 percent of the total allowable ballot papers for the Abau electorate. In 2003 there had been 345 informal ballots. However, the low level of informal ballots could also be attributed to the way assisted voting is conducted (see below).

\section{HIV/AIDS awareness}

Most election observers reported that HIV/AIDS was not a prominent election issue. References were made to HIV/AIDS as a social and development issue in some of the candidates' campaign speeches, but it was not a significant factor in the calculus of the voters. The only HIV/AIDS materials sighted were in aidpost buildings.

With one exception, candidates for the Abau electorate were not members of provincial or district AIDS Committees and they were not engaged at the policy level and so had no clear strategies for addressing the effects of HIV/AIDS on the people of Abau. The exception was Dr Puka Temu, a former Health secretary and a member of the Parliamentary Committee on HIV/AIDS. Temu was involved in 
decision-making on strategies to deal with HIV/AIDS at the national, provincial and district/LLG levels, and campaigned on HIV/AIDS issues throughout the electorate.

No materials on HIV/AIDS testing or voluntary counselling were seen in the Aroma LLG area. The awareness situation was different in Amazon Bay. Freda Magini, Lahui Magini and Fred Mae, who were members of the Amazon Bay HIV/AIDS Committee, conducted election observations in Amazon Bay and reported that male and female condoms were distributed by them, in their roles as the HIV/AIDS Committee members and as implementers of election awareness, during the campaign period. According to Mae, both men and women openly accepted the condoms.

Random interviews conducted with individual voters in Kupiano, Viriolo, Kapari and Lalaura wards suggest that development projects that enhance the delivery of basic services and generate income were considered directly beneficial in improving people's living standards. While HIV/AIDS was seen as a significant issue among the people, it was not seen as being directly linked to people's incomes.

Drugs such as marijuana were not used during campaigning, and there were no '6-to-6 discos' or prostitution during the election period to warrant concern about election-related activities that could contribute to the spread of HIV/ AIDS. The team did not see evidence of weapons of any sort in the hands of supporters or citizens. ${ }^{2}$

The churches, through leadership of the elders, have a strong influence in Abau and this was a major factor in explaining why drugs and other unacceptable social behaviour were not evident during the election period.

\section{The campaign}

The campaign period lasted eight weeks, from 4 May to 29 June 2007. This timeframe was generally considered adequate, as a longer period would have exhausted the energies and resources of the candidates and their supporters.

The campaign was generally peaceful; there were no reported instances of threats, violence or disruptions. LPV had some influence on the way campaigning was done: candidates saw the need to exchange second and third preferences and in some instances candidates campaigned for each other in areas that were not

2 The prevalence of general peace and order across the electorate throughout the election period was noted in all team members' election journals. 
their strongholds. Candidates were generally free to move around (as they did in Abau in 2002 under the first-past-the-post system) and most candidates ran their campaigns independently of each other.

Only five candidates campaigned in the Amazon Bay LLG area (in the eastern part of the Abau electorate). They included Puka Temu, Kilroy Genia and Reuben Kaiulo. Freda Magini, Lahui Magini and Fred Mae concluded that this was due to financial and logistic constraints, as well as limited networks for some of the candidates.

The candidates' campaign strategies included public speeches, handing out T-shirts, and the display of posters on public motor vehicles, house walls and trees. Only a few, including Temu and Genia, held public rallies. Most campaigned in their local LLG wards, though Temu, Genia and Kaiulo campaigned across the Abau electorate. These three sought any preferences, but expected to get first preferences from their local strongholds and second and third preferences from wards which they knew were the strongholds of their rivals. Other candidates campaigned in their local areas mostly for first preferences.

Campaign rallies were organized for Temu and Genia. The Enara family organized a rally for Temu at Maopa One, Paramana, in the Aroma LLG, at which Temu was the only candidate to speak. A National Alliance official, Tau Po'o, was present to give support. Temu talked about health and education services, economic development projects, good governance, women's rights and HIV/AIDS issues. He campaigned for first preferences only, probably because he felt that the voters he was addressing were his strong supporters.

The audience was made up of a good cross-section of the community-men, women, youth and children. Although the rally was open to all, it was mostly men who spoke, on various issues. At one stage, supporters of rival candidates attempted to disrupt the rally, which went on into the night.

Genia staged a peaceful rally at Lalaura village/ward, where he was the only candidate to address the audience. Like Temu, he talked about better health services, free education, and development projects that would generate income for the people, and good governance. He did not talk about women's issues, nor did he talk about HIV/AIDS. Genia considered the ward that hosted the rally as a stronghold and accordingly did not campaign for second and third preferences; he asked only for first preferences and informed voters how to allocate their preferences at the time of polling. He did not talk negatively about any of the other candidates.

However, most candidates relied primarily on their campaign managers and committees, and the use of campaign posters. One candidate (Desmond Baira) made an effort to transport truckloads of supporters from the Wanigela 
settlement at Koki (Port Moresby) to Wanigela in the Aroma LLG area, as he had in the 2003 by-election. Some of the Koki-based Wanigela voters subsequently revealed that they had voted more than once while at Aroma. Election observers in Abau were of the view that voters had access to the ward roll prior to polling and were therefore aware of the names of deceased voters and voters who had moved residence and were no longer living at Wanigela at the time of polling.

One candidate - Vagi Mae, from Maopa in the western part of the Aroma LLGwas seen as a vote splitter, so that Temu and Kaiulo would be denied votes in western Aroma. The counting of votes from ballot boxes in western Aroma showed, however, that his candidacy did not have a significant impact, as Temu picked up a significant number of votes in those wards.

\section{Political parties}

Seven political parties endorsed candidates for the Abau seat. Puka Temu was endorsed by National Alliance, Kilroy Genia by PNG Party, Desmond Baira by People's Labour Party, and Reuben Kaiulo by Pangu Pati. The National Advance Party, the People's Resources Awareness Party, and the People's Progress Party also endorsed candidates. The remaining five stood as independents.

National Alliance's endorsement of Temu did not come as a surprise. He was a popular candidate in the 2002 election and again in the 2003 by-election. He had also established a strong following among the voters in the Amazon Bay, Cloudy Bay and Aroma Coast LLG areas. Among the development projects he had initiated were a rural market in Kapari-Viriolo village and the sealing of 10 kilometres of the Magi Highway from Omen Bridge in Eastern Rigo to Bukuku Junction in the Abau area. The sealing was carried out by Global Construction, a local construction company. Temu was also responsible for the introduction of a cassava ethanol project in Cape Rodney as well as collaboration with the National Agricultural Research Institute to render advice and other assistance to farmers in the Abau District. He had used his electoral funds to purchase water tanks for communities in Amazon Bay, dinghies for communities in the Aroma and Cloudy Bay areas, and a tractor for communities in the Cloudy Bay area. Temu had other development projects in mind in the ecotourism and forestry sectors as part of his vision for the development of Abau. He had proven his ability to deliver vital services and to adapt himself to the needs of the people of his electorate.

Kilroy Genia first entered parliament in a 1994 by-election following the death of his brother and Pangu Pati leader, Jack Genia. He contested the seat as a Pangu candidate and won again in 1997. In 2002, he re-contested the seat as a People's Democratic Movement candidate and came third with 19 percent of the 
vote. In the 2003 by-election, he contested as a People's Action Party candidate, gaining 20 percent of the primary vote plus preferences. Aside from his party hopping, Abau District had not seen major improvements in services between 1994 and 2002 during Genia's term as MP, which may have eroded his popularity and explain his performance in the 2002 and 2007 elections. In 2007 he was endorsed by the PNG Party, though he received little support from the party.

Desmond Baira was endorsed by the People's Labour Party, headed by Madang businessman Peter Yama. Baira had contested the seat in 2002, endorsed by the People's Action Party, coming second with 23.7 percent of the vote. He had also stood for the seat in 1992, 1994 and 1997.

Reuben Kaiulo, the former electoral commissioner, was endorsed by the Pangu Pati, but received little support from the party.

Of the parties that endorsed candidates, the leaders of the National Alliance and People's Labour Party campaigned in support of their candidates within the electorate. National Alliance leader, Sir Michael Somare, was in Kupiano to inform people about the party's development policies and to campaign for Temu. He emphasized that Temu had solid public service experience, proven leadership ability, and a track record of delivering tangible services during his last term of office from 2003 to 2007. According to Somare, Temu was the best choice for the people of Abau and National Alliance was privileged to endorse him.

People's Labour Party leader Peter Yama came to Wanigela to campaign for Baira, who had been a strong contender in previous elections. Although Yama recognized that Baira had no prior political leadership experience, he drew attention to his business skills and practical experience which Yama felt were necessary for the delivery of basic services.

Overall, political parties did not have a strong presence in the Abau electorate during the elections, which may partly explain why voters still vote predominantly along personal and clan lines. Parties do not have much relevance to voters.

\section{Gender issues}

Women voters throughout the electorate generally understood the LPV system and most voted freely throughout the polling period. ${ }^{3}$ Some candidates, for example Temu, campaigned explicitly on women's issues in a bid to secure

3 In the Kupiano, Kapari and Lalaura wards where I observed polling, women were generally free to vote. Peace and order were maintained throughout the entire electorate in 2007. 
women's votes. Notable topics were the lack of women in politics; discrimination against women; women's employment, especially in managerial positions; and HIV/AIDS and sexual health issues. There appears to be a growing concern for such issues among people throughout the electorate, but despite this no women candidates contested the Abau seat in 2007 and none of the candidates was an active member of civil society groups within the electorate.

Women in Abau were generally not a subject of much interest to candidates, party officials, campaign managers, supporters, electoral officials or police. Women's issues, such as gender empowerment, women's participation in the informal economy and increased enrolment for girls in community schools, did not figure prominently in candidates' campaigns. Observers noted that while some candidates made reference to gender issues, there was lack of specific policy platforms, even for those who made reference to women's issues. By implication, most women voted for candidates on the basis of proposed income generation projects and vague references to health, education and other basic services. Candidates were aware of issues that had an electorate-wide appeal and those that would appeal to a segment of the voting population or to a specific locality. They focused on collective and local issues and avoided issues that would fragment the vote.

An exception was the Amazon Bay HIV/AIDS Committee, which carried out awareness on gender issues, covering women and the elections in Abau, lack of women in politics, women's voting rights, discrimination against women, and HIV/AIDS and women.

Some women campaigned publicly for Temu, otherwise most women were involved in cooking food and providing hospitality. There was no intimidation of women during nominations, campaigning, polling or counting periods.

\section{Polling}

There were 29 polling teams. Most officials were men. Cooperation between the polling officials and the Abau observer team was good. Polling officials did not always arrive on time $(8 \mathrm{am})$ to commence voting. In Paramana, for example, polling started one day at 1:50 pm. Late polling was also observed in the Lalaura ward, where it continued into the second day. In Amazon Bay, polling commenced late due to bad weather and the consequent late arrival of ballot boxes and materials.

In Kapari and Lalaura wards, there was no gender segregated voting. Moreover, the polling compartments were not always positioned to screen the voter from 
observation, and thus did not ensure a secret ballot. In many polling stations in Aroma, and also in Cloudy Bay and Amazon Bay, there was only one ballot box for both the provincial and open seats.

Scrutineers were instructed by polling officials to stay 10 metres away from the polling area to prevent any kind of undue influence on voters. They were generally well behaved.

The PNGEC's candidate posters for Abau Open and Central Provincial electorates were displayed in public places, as well as in the polling compartments. This allowed voters to think about their choices and decide how to allocate their first, second and third preferences. Presiding officers explained the polling procedures to the voters before they proceeded to the polling compartment, though nobody explained the procedures for gender segregated voting.

Prior to polling, the ballot boxes were opened by the presiding officer in the presence of scrutineers, voters and police, and shown to be empty. At the end of polling, the boxes were fastened with a numbered inner tag and outer seal.

If a voter required assistance to vote, he/she could request a family member or policeman to assist. Practices varied from polling station to polling station. In Kapari ward, for example, family members were used most of the time when voters needed assistance; over two days 221 women were assisted. In Amazon Bay, Freda Magini noted that in one polling station, a police officer was used more than 50 times to help voters who needed assistance. Observers reported that assisted voting was sometimes abused, particularly when women and older non-literate voters were assisted by male supporters of particular candidates.

Polling was generally peaceful and orderly. Voters generally formed queues and voted in order of arrival. Their fingers were checked for ink as they entered the polling area, and ink was applied before they proceeded to vote. In a few polling places, voters' names were called alphabetically from the electoral roll. Polling officials had little difficulty locating names on the alphabetical electoral roll, though in some instances, legitimate voters were denied the right to vote due to misspelling of names, two voters' having the same name, or because their names were not on the roll.

There were reports, notably from some polling stations in the Amazon Bay area that supporters gave out candidate posters and bio-data to voters while they were on the queue waiting to vote, and told the voters (especially women voters) to vote for particular candidates, but on the whole the atmosphere was voter friendly and conducive to voting.

Voter turnout was generally good in all polling stations. Over 74 percent of the 29,652 people enrolled turned out to vote. 


\section{Electoral roll}

The rolls, based on LLG wards, were generally satisfactory, but certainly not perfect. In a number of instances, voters could not find their names on the roll. One observer noted that in Paramana as many as 50 voters were turned away, and in Amazon Bay 11 voters were turned away because their names were not on the ward roll. In the Wanigela ward, Aroma, where, as noted above, Port Moresby-based voters were allowed to vote in their place or origin, there were instances of multiple voting through the use of other people's names. At the Magarida polling station, in Amazon Bay, a number of underage persons were allowed to vote as their names were on the ward roll. A school teacher at the Magarida High School confirmed that the persons who voted were in fact school students under the age of 18 .

\section{Personnel, security and inter-agency communication}

Police personnel arrived in the electorate four days prior to polling and were deployed to the appropriate LLGs on polling day. As usually happens, police had received their allowances before being deployed for polling. However, the deployment was delayed by the non-payment of allowances for electoral officials, and delayed payment for land and sea transport. There was no air transport to move police personnel to location for security duties. Once at their respective LLGs, police were properly accommodated in local guest houses and with local families.

Communication between police and the PNGEC was good in the pre-polling and polling periods, and police and polling officials were seen working together at the polling places. Each polling team had about four police personnel to provide security.

Security was generally good throughout the Abau electorate. Voters and police cooperated with one another, ensuring the safety of the ballot boxes, ballot papers, and polling officials. The general peace and order was widely considered to be an improvement on that in 2002 and was a major factor in the integrity of the election in Abau. Voters were not intimidated. Guns were generally not carried around by police, and police made no arrests. 


\section{Counting}

Because of disruptions to counting in the 2003 by-election, counting for Abau Open was moved to Murray Barracks in the National Capital District, just as in 2003 when the count was conducted at the Institute of Public Administration Hall, National Capital District. It took about 10 days, from 13 to 23 July, 2007, to complete the count. Counting was suspended mid-way into the week as scrutineers did not want the returning officer to be present in the counting room, lest he influence the course of counting. They argued that the returning officer was associated with a particular candidate. The scrutineers stood their ground, forcing the counting officials to liaise with PNGEC, whose lawyer intervened to sort out the matter. A consensus was reached and counting resumed on the condition that while the returning officer would be present in the counting room, the provincial returning officer would be responsible for the counting.

The counting room was spacious and there was a heavy police and army presence around the clock. Scrutineers and observers were allowed into the room to observe all phases of the counting. The progressive tallies were put up on a tally board at the back and front of the room; the figures were clear enough for all to see.

At the start of count for each box, the provincial returning officer announced the presiding officer who was responsible for the box. The presiding officer gave a brief account of events in the ward(s) concerned. A policeman who had accompanied the team then opened the box and emptied the ballot papers onto a sorting table. Sorters (a number of whom were women) were then called to sort out the provincial from the open ballot papers. Provincial ballot papers were then transferred, under police guard, to the other side of Murray Barracks where counting for the Central Provincial seat was going on.

A second set of sorters then sorted the open ballot papers by first preferences, which were then counted. Although Puka Temu led from the beginning he did not secure an absolute majority of the first preferences, so losing candidates were eliminated and their preferences distributed.

Security in the counting room was excellent and the scrutineers were well behaved throughout the counting and accepted the final outcome.

\section{The outcome}

Twelve candidates contested the Abau Open seat. When counting began, the top four contenders were Puka Temu, Kilroy Genia, Desmond Baira and Reuben 
Kaiulo. After the count of first preferences, Gideon Aruai with 50 votes was eliminated and his voters' preferences distributed. The second exclusion was John Maru, with 93 votes. David Rakilea was the third to be eliminated, with 133 votes. There followed Vagi Mae (163 votes), Stephen Mera (364 votes), John Holland (546 votes), Gavu Lama (752 votes) and Onea Thavala (978 votes). Reuben Kaiulo was ninth exclusion, with 3517 votes.

At the ninth exclusion, 9698 became the absolute majority of the total 'live' remaining votes. At this point, Temu, having led all the way, had secured 10,772. His closest rivals were Desmond Baira with 4328 votes and Kilroy Genia with 4295 votes. Temu was therefore declared the winner by the provincial returning officer.

Temu led comfortably from the start, with 9578 first preferences (43.5 percent of the total allowable votes) compared to his nearest rival, Baira, with 3395 (15.4 percent), and led all the way to the declaration. Temu was popular across the across the electorate, picking up 1194 preferences (to give him a total of 48.9 percent of the total allowable votes). Baira was the eventual runner-up, collecting 933 preference votes (mostly from the eighth and ninth exclusions). Genia picked up 1078 preferences to finish third, and Kaiulo, with 483 preferences came in fourth. These four candidates consistently gained a good share of the preferences from eliminated candidates.

Exhausted ballot papers (2640) represented about 12 percent of the total allowable ballots at the ninth exclusion, which was a reasonably low level of exhausted ballots.

Temu's victory can be attributed to a number of factors. During the elections, he campaigned in almost every ward in the Aroma, Cloudy Bay and Amazon Bay LLG areas. Visiting, meeting and talking to people, and shaking hands with voters, is very important for any candidate, and Temu was able to do that quite effectively. His campaign gatherings drew huge crowds of men, women and youth. Even those who were not his supporters, in all three LLG areas, were eager to hear how he would bring basic services to their communities. For the people of Abau, Temu had proven that he could deliver vital services. They also knew that he had a vision for the electorate. None of the other candidates had a comparable track record of achievements and proven leadership ability.

Temu's popularity goes back to 2002, when he first contested the Abau seat under the first-past-the-post voting system. Despite a court ruling nullifying his election victory, his popularity continued in the 2003 by-election. Standish et al. (2004:2) observe that 'most candidates only had strong local support in certain concentrations. The exception was Dr Temu who had campaigned widely and had strong support across the three rural local level governments (RLLG) 
council areas in the electorate'. In the 2003 by-election, Temu collected 8911 first preferences (48.79 percent of the primary votes), and 9113 (50.09 percent) of the final count. He has had a consistent level of popularity among the people in all the three LLG areas since 2002.

Temu, Genia, Baira and Kaiulo are all from the Aroma LLG area. All four are well educated and experienced in administration and politics. Aroma thus continued to dominate Abau electoral politics in terms of both candidate numbers and election outcomes, as it did in 1997, 2002 and 2003.

\section{Conclusion}

Temu had a commanding lead in the primary vote and continued to lead in the count of preferences up till the declaration. He was popular across the Abau electorate. Voter participation was high, suggesting that Abau people valued the election as well as their participation and the need to elect a capable leader. Having the nominations done at the district office in Kupiano may have stimulated community interest (as in the by-election in 2003). Informal ballot papers were less than 2 percent, suggesting that the awareness had improved voters' understanding of how to vote correctly, though 'abuse' of assisted voting may have played a part in the low informal vote. This was evident in 2003, where every one of the 3865 votes collected from the Wanigela village were 'assisted' by the 'helpers' provided by candidates - even the local candidate. Exhausted ballot papers were around 12 percent of the total, the relatively low figure linked to the small number of candidates.

Candidates and voters need to realize that elections provide opportunities for political and civic education including awareness. There is, briefly, an intense interaction between candidates and voters, in which candidates are eager to talk about policies and issues while voters are eager to listen, learn and choose their candidates. In this context, it is important for candidates to address important issues such as HIV/AIDS and women's empowerment.

There was limited collaborative and cooperative campaigning between candidates with a view to exchanging preferences, as was expected to happen under LPV. Aside from financial and logistical constraints, some candidates did not address strategic campaign matters such as establishing committees in other LLG areas which could plan and organize their campaign activities.

Certain groups engage in multiple voting through abuse of the electoral roll. The roll needs improvement in terms of eliminating multiple entries of voters' names, names of under-aged persons and other irregularities. Public display of the roll during the verification stage, prior to polling, could help people take 
ownership of the roll. This was not done at the Kupiano district headquarters. Assisted voting was sometimes abused to ensure that voters voted for certain candidates. Electoral and civic awareness could make voters aware of their rights to a secret ballot.

On the whole, well-managed security operations in all aspects of the election in Abau, from nomination to counting, combined with cooperation between the people, candidates, supporters and polling officials, led to a peaceful, orderly election and an undisputed declaration of Temu as Abau's duly elected MP.

\section{References}

Kaiulo, Reuben, 2002. 'Report to the Sixth Parliament on the 1997 National Election by the Electoral Commissioner', in R. J. May and R. Anere (eds), Maintaining Democracy: The 1997 Elections in Papua New Guinea. Port Moresby: Department of Political Science, University of Papua New Guinea, and State, Society and Governance in Melanesia Project, The Australian National University, pp. 169-180.

National Statistical Office, 2000. Papua New Guinea 2000 Census: Central Province. Port Moresby: National Statistical Office.

Standish, Bill, with Alphonse Gelu, Henry Okole, Orovu Sepoe, Agaru Kaiulo and Cecily Kome, 2004. 'Limited Preferential Voting in Papua New Guinea: Report on Abau By-Election of December 2003'. Unpublished report. Canberra.

\section{Appendix}

\section{Table 14.1: Voting statistics for Abau Open electorate, 2007 election}

\begin{tabular}{lrr}
\hline Number of registered voters & 29,804 \\
Total votes cast & 22,365 \\
Informal votes & $328 \quad$ (1.5\% of total votes cast) \\
Total allowable ballot papers & 22,037 \\
Total ballot papers remaining in count & 19,395 \\
Total votes distributed & 9,064 \\
Exhausted ballot papers & $2,642 \quad$ (12\% of allowable ballots) \\
Absolute majority $(50 \%+1)$ & 9,699 \\
\hline
\end{tabular}


14. The Abau Open Electorate: A Second Go at LPV

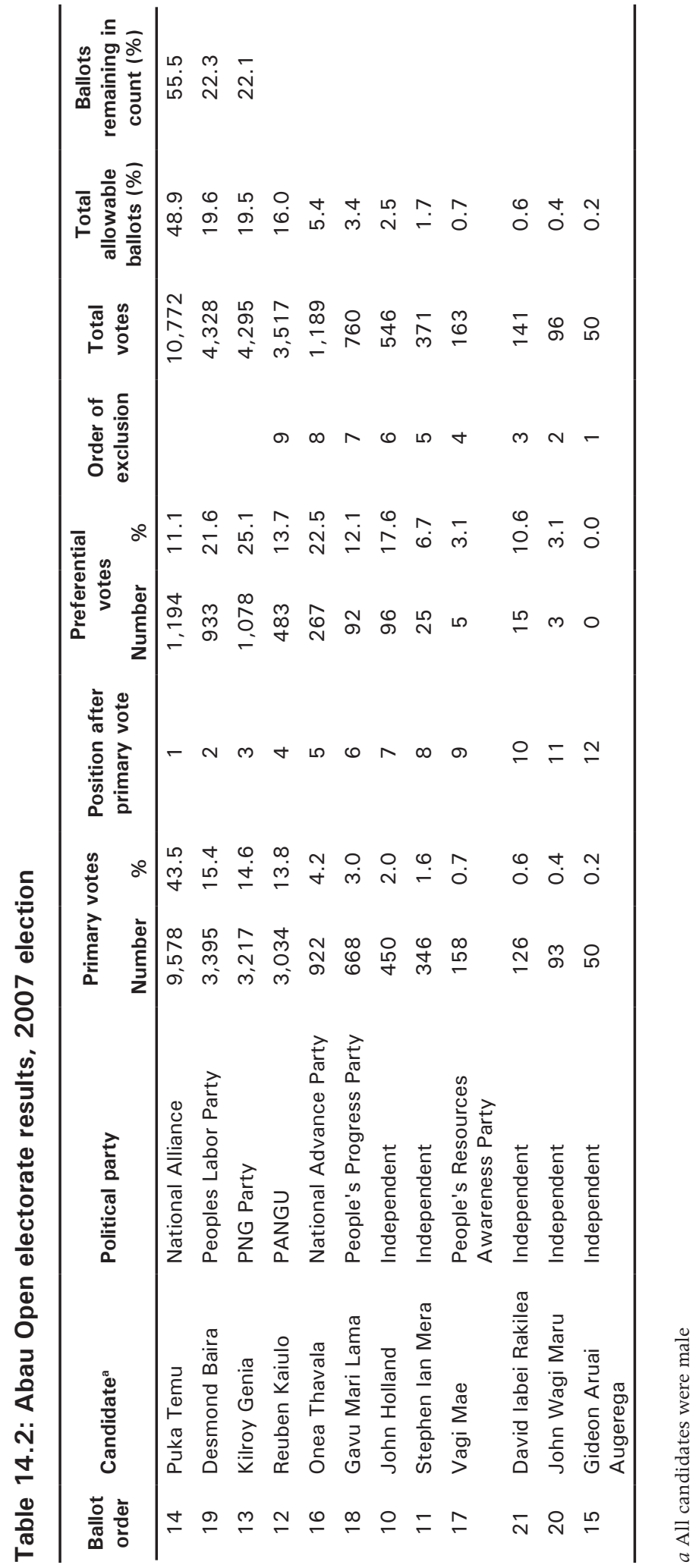

